\title{
Seasonal Changes in Ovarian Follicle Growth in Iran Viper (Vipera albicornuta)
}

\author{
Nousha Afsharzadeh, ${ }^{1}$ Abdolhossein Shiravi, ${ }^{1}$ and Fatemeh Todehdehghan ${ }^{2}$ \\ ${ }^{1}$ Azad Islamic University, Damghan Branch, Damghan 3671639998, Iran \\ ${ }^{2}$ Venomous Animals \& Antivenin Production Department, Razi Vaccine and Serum Research Institute, Hesarak, \\ Karaj 3197619751, Iran
}

Correspondence should be addressed to Fatemeh Todehdehghan; f.todehdehghan@rvsri.ac.ir

Received 17 August 2015; Revised 28 October 2015; Accepted 1 November 2015

Academic Editor: Ida Sigueko Sano-Martins

Copyright (C) 2015 Nousha Afsharzadeh et al. This is an open access article distributed under the Creative Commons Attribution License, which permits unrestricted use, distribution, and reproduction in any medium, provided the original work is properly cited.

The Vipera albicornuta is an economically important snake of Iran, its venom is used for antivenin production, and we need to breed the snake in the captivity. In order to know about the viper's reproductive biology, seasonal alterations in ovarian weight, morphology, and the follicles developmental stages in Vipera albicornuta were studied using macroscopic parameters and histological examination of reproductive tissues during a year. Twenty-four female vipers were collected from mountainous zone of Bostanabad, East Azerbaijan, and Tarom in Zanjan through years 2011-2012. Evaluation of the reproductive parameters of this viper is performed for the first time in Iran. Our observation revealed that vitellogenesis cycle begins in autumn and continues till early summer; ovaries and follicles are in previtellogenesis stage in autumn and vitellogenesis in winter and during spring. Weight of ovary is heaviest in spring, ovulation occurs in late spring till early summer, and copulation is prior to ovulation.

\section{Introduction}

Vipera albicornuta, locally named Zanjani viper, belongs to Viperidae family, Vipera genus, and Montivipera subgenus. The geographical distribution of this species is in Northern Iran, covering several areas of the Northern Zagros and provinces of Gilan, Qazvin, Zanjan, and East Azerbaijan [1]. The aim of this study is to provide data on the reproductive biology of female $V$. albicornuta using histomorphologic and histomorphometric investigation on the female reproductive organs through a year.

Female reproductive system consists of one pair of the long ovaries that sometimes contain follicles, which are located at back by abdominal mesoderm and are in anterior oviducts that open to cloacae [2]. The right ovary is located slightly higher than the left ovary [3]. The ovaries in the reptiles are composed of stromal and parenchymal tissues. Structural and morphological changes in ovaries size and weight occur during reproductive cycle. Reptilian reproductive cycles are normally affected by environmental factors, among which temperature and light are clearly environmental cues controlling the reproductive cycles of lizards and snakes [4]. The reproductive cycle of female snakes is in relation to reproductive cycle of male and climate. In this regard there are prenuptial and postnuptial cycles. In the prenuptial cycle, female ovulation follows the peak of spermatogenesis but in postnuptial cycle there is a latency period over winter, from completion of spermatogenesis to fertilization, but there is no such latency in the prenuptial cycle [5].

Ovarian follicles are 3 types: previtellogenic, vitellogenic, and atretic. The development of the egg yolk in the follicles starts when estrogen stimulates the liver to start converting lipids from the body's fat stores, creating vitellogenin. During atresia the theca interna is greatly hypertrophied and is loaded with lipids consisting of first phospholipids and then phospholipids and finally triglycerides, cholesterol and its ester, and little phospholipids. Eventually the oocyte, zona pellucida, granulosa cells, and most of the cells of theca interna regress and disappear, leaving behind some residual cells of theca interna. Histological examination of ovaries in 
monocled cobra Naja kaouthia in May shows high number of pyriform cell in the granulose layer. Pyriform cell is classified into the 3 sizes, including small, medium, and large [6]. The squamate granulose contains a pyriform cell that is in direct contact with a developing oocyte apparently involved with early steps in oocyte's development as granulose cells either degenerate or transform into typical granulose cells soon after the onset of vitellogenesis as the time of ovulation approaches. The granulose cells and some theca cells accumulate cholesterol-positive lipids and, following ovulation, proliferate and luteinize to form the corpora lutea [7]. Development of the primary oocyte consists of 3 phases: previtellogenic, vitellogenic, and maturation step [8]. During vitellogenesis the yolk is added to the oocyte arrested in meiosis diplotene stage and maturation leads to ovulation; after that the ovulation female gamete is called ovule. At this time oocytes are large and yolk is in large quantities also and chorion is surrounding them. Vitellogenesis in the Bothrops insularis occurs in spring and ovulates in late spring. In most of snakes vitellogenesis begins after waking up from hibernation in spring and is peak at ovulation time [9]. In a study on development of follicles in brown snake Storeria dekayi it is reported that the follicles at the different developmental stages have different length, the length of primary follicles was $1.0-1.5 \mathrm{~mm}$, that of vitellogenic follicles 1.6$3.0 \mathrm{~mm}$, developing follicles during late winter or early spring in mature female, and that of developed follicle $6.1-12.0 \mathrm{~mm}$ [10]. Many of the follicles that grow in the ovary and lead to ovulation have diameters not more than $10 \mathrm{~mm}$. In some species one or two follicles are ovulated and others are resolved and absorbed in ovary [11].

Ovulation in spring is compatibility to finalize pregnancy in female; for the reason that environment temperature is high during this season embryonic growth is rapid and abnormal growth is decreased [12]. Lizard that has delayed in reproduction has enough stored abdominal fat that has been able to make large size clutch [13]. There is the relationship between body size and clutch size [14].

The lizards that have large body cavities are largest and have greatest potential to foster more pups or produce more ovum and species that have diversity in body size also are expected to be various in clutch size [15]. Variation of clutch size is ancestral state in reptiles [16]. Food and available resources in reptile have the positive effect on clutch size [17].

\section{Materials and Methods}

In this research, ovaries morphology and stages of ovarian follicle growth were examined in Vipera albicornuta during 4 seasons for this purpose, so twenty-four $V$. albicornuta snakes were collected from Bostanabad in Azerbaijan and Tarom districts in years 2011 to 2012. Samples were collected and transferred to the Laboratory of the Venomous Animals Department in RAZI Institute and the snakes were parasiticide with antimite ivermectin $1 \%$ and kept in temperature between 20 and $30^{\circ} \mathrm{C}$ and to be sure of their health they were caged for quarantine. Snakes were anesthetized with lidocaine $1 \%$ injection around cloacae, and then they were killed with alcohol 96\%. Body weight and length (SVL,
Snout-vent length) and tail length (TL) were measured with the meter. The snake was dissected and abdominal region was incised in the sterile condition and abdominal fat was removed and weighed. Ovaries were removed, their weight was measured by digital scale (OSK, FX 3000, 0.0001 g) and length, width, and thickness were measured by a digital caliper [18]. Numbers of ovarian follicles were counted and their diameters were measured by micrometer under stereomicroscope (SZX-1LLB2-200) as described by Betz [19]. For histological examination, samples were fixed in formalin $10 \%$ MERK and histological processing of tissues was performed on paraffin section stained with hematoxylin and eosin method and the tissue was cut in cross section to $5 \mu \mathrm{m}$; then slides were examined under light microscope same as Luna [20].

2.1. Samples Collection Areas. Bostanabad is located in the Eastern Azerbaijan Province of Iran, a mountainous zone with cold winter and temperate summer and altitude from sea level is 1740 meters. The coldest temperature for two years in February 2012 was $-25 / 6$ and in January $2013-18 / 6^{\circ} \mathrm{C}$ (Figure 1). Tarom is located in Zanjan Province of Iran and is located in high mountains and has cold and snowy winter, mild and dry summer (Figure 2).

2.2. Statistical Analysis. Student's $t$-test was performed for comparison of two values by Quick Graph software in windows. Descriptive values were presented as mean and standard deviation.

\section{Results}

The morphometrical parameters of viper are shown in Tables 1 and 2. The results show that body weight is increasing in fall and it is decreasing in winter during rest and during vitellogenesis, and in spring it rises up and descends in summer again (Tables 1 and 2). Maximum body weights of Bostanabad's samples were $213.33 \pm 30$ and $204.06 \pm 1.32 \mathrm{~g}$ and for Tarom's samples were $142.82 \pm 31.41$ and $136.66 \pm 30.5 \mathrm{~g}$ in spring and fall, respectively. Maximum average of body length in Bostanabad's samples was $68.43 \pm 2.98 \mathrm{~cm}$ and for Tarom's was $63.96 \pm 3.77 \mathrm{~cm}$ (Tables 1 and 2). Our result indicated that the right ovarian weight and numbers of follicle were more than the left ovary in Bostanabad viper as well as in Tarom snake. Maximum ovarian weight of Bostanabad's snakes was observed in spring and minimum weight in winter and for Tarom's samples is in spring and summer (Tables 3 and 4). Long length of ovarian follicles in Bostanabad's vipers was $6.20 \pm 1.60 \mathrm{~mm}$ in spring and short length is $4.43 \pm 1.85 \mathrm{~mm}$ in right ovary whereas in the Tarom's snakes the long follicles with the length of $7.05 \pm 2.34 \mathrm{~mm}$ were observed in the left ovary in spring and the short follicles with the length of $3.75 \pm 1.43 \mathrm{~mm}$ were seen in the right ovary in summer. The size of ovarian follicles in the Bostanabad snakes was largest and may have ovulated between late May and June (Figure 3) and in the Tarom's snakes largest follicles and ovulation time were seen in May (Figure 4). Histological study revealed that vitellogenic follicles were observed in the ovaries from 


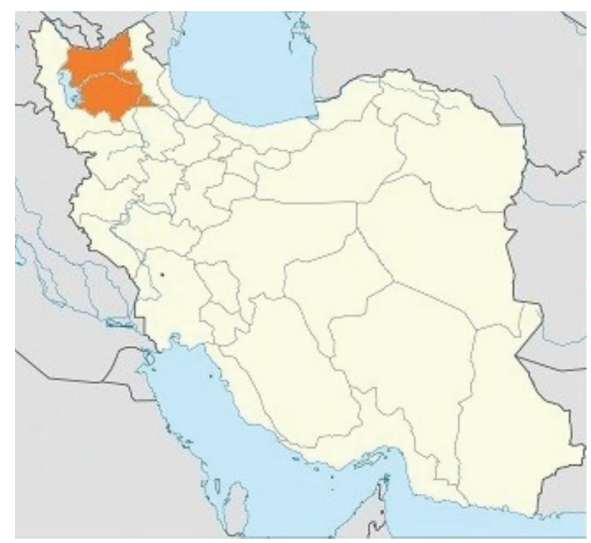

(a)

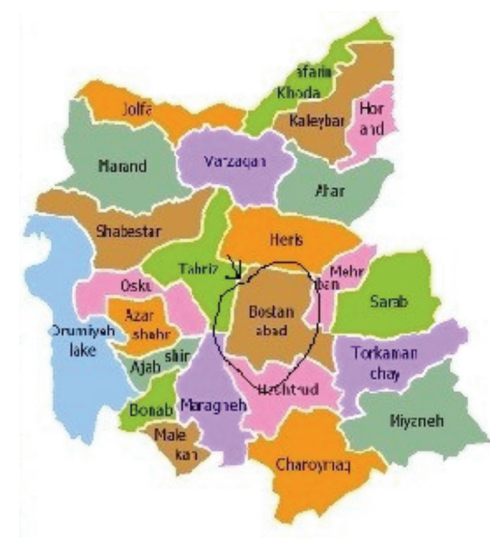

(b)

Figure 1: Geographical map of East Azerbaijan Province (a), Bostanabad (b).

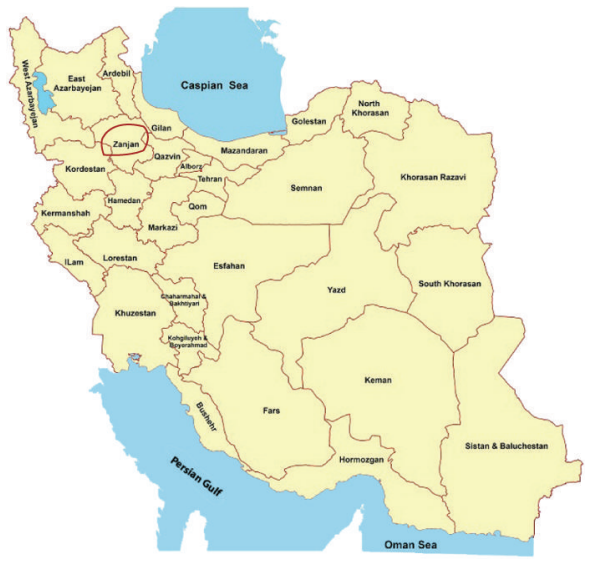

(a)

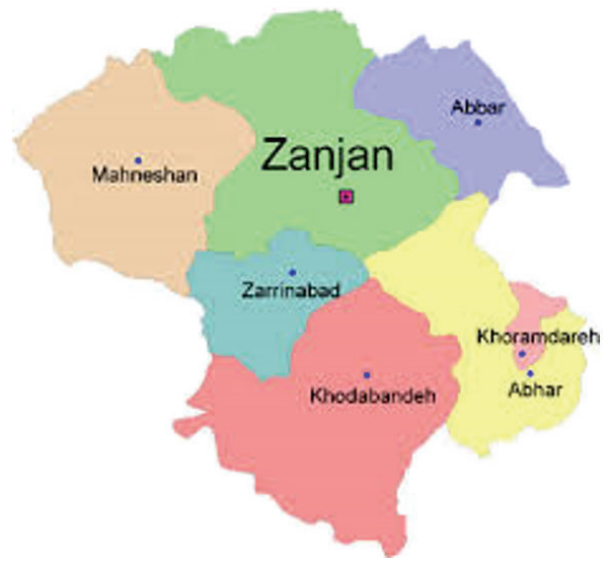

(b)

Figure 2: Geographical map of Zanjan Province (a); Zanjan, Tarom (b).

TABLE 1: Mean values of morphometric parameters from Bostanabad Zanjani viper in four seasons $(\mathrm{M} \pm \mathrm{SD})$.

\begin{tabular}{|c|c|c|c|c|}
\hline \multirow{2}{*}{ Parameters } & \multicolumn{4}{|c|}{ Season } \\
\hline & Spring & Summer & Autumn & Winter \\
\hline \multicolumn{5}{|l|}{ Body length $(\mathrm{cm})$} \\
\hline Total & $73.87 \pm 3.58$ & $71.25 \pm 2.88$ & $71.13 \pm 1.58$ & $65.61 \pm 5.73$ \\
\hline SVL & $68.43 \pm 2.98$ & $67.01 \pm 3.07$ & $64.63 \pm 2.99$ & $60.66 \pm 5.34$ \\
\hline $\mathrm{TL}$ & $5.43 \pm 0.67$ & $5.1 \pm 0.37$ & $5.38 \pm 0.16$ & $4.95 \pm 0.39$ \\
\hline \multicolumn{5}{|l|}{ Weight (g) } \\
\hline Body & $213.33 \pm 30.00$ & $162.72 \pm 36.76$ & $204.06 \pm 1.32$ & $126.83 \pm 45.27$ \\
\hline Fat & $24.45 \pm 4.33$ & $15.05 \pm 10.03$ & $24.93 \pm 5.62$ & $13.11 \pm 11.59$ \\
\hline \multicolumn{5}{|c|}{ Body diameter (cm) } \\
\hline Neck & $4.91 \pm 0.21$ & $4.78 \pm 0.19$ & $4.86 \pm 0.05$ & $4.28 \pm 0.29$ \\
\hline Vent & $8.50 \pm 0.59$ & $7.75 \pm 0.71$ & $8.39 \pm 0.74$ & $6.78 \pm 0.70$ \\
\hline Upper caudal & $4.85 \pm 0.36$ & $4.73 \pm 0.33$ & $5.01 \pm 0.63$ & $4.08 \pm 0.30$ \\
\hline \multicolumn{5}{|c|}{ Orifices diameter $(\mathrm{mm})$} \\
\hline Cloacae & $4.25 \pm 1.42$ & $3.40 \pm 0.83$ & $2.63 \pm 0.45$ & $2.52 \pm 0.09$ \\
\hline Vagina (right) & $2.03 \pm 0.76$ & $1.47 \pm 0.33$ & $1.76 \pm 0.37$ & $1.84 \pm 0.31$ \\
\hline Vagina (left) & $2.05 \pm 0.52$ & $1.49 \pm 0.48$ & $1.55 \pm 0.37$ & $1.89 \pm 0.32$ \\
\hline
\end{tabular}


TABLE 2: Mean values of morphometric parameters from Tarom Zanjani viper in four seasons $(M \pm S D)$.

\begin{tabular}{|c|c|c|c|c|}
\hline \multirow{2}{*}{ Parameters } & \multicolumn{4}{|c|}{ Season } \\
\hline & Spring & Summer & Autumn & Winter \\
\hline \multicolumn{5}{|l|}{ Body length $(\mathrm{cm})$} \\
\hline Total & $64.02 \pm 4.83$ & $67.66 \pm 2.76$ & $64.55 \pm 6.89$ & $61.16 \pm 1.23$ \\
\hline SVL & $59.28 \pm 4.49$ & $63.96 \pm 3.77$ & $59.31 \pm 6.61$ & $56.08 \pm 1.11$ \\
\hline $\mathrm{TL}$ & $4.91 \pm 0.53$ & $4.88 \pm 0.31$ & $5.24 \pm 0.50$ & $5.08 \pm 0.35$ \\
\hline \multicolumn{5}{|l|}{ Weight (g) } \\
\hline Body & $141.82 \pm 31.41$ & $136.66 \pm 6.83$ & $131.66 \pm 30.51$ & $107.49 \pm 1.18$ \\
\hline Fat & $13.93 \pm 3.98$ & $12.93 \pm 3.61$ & $12.41 \pm 3.55$ & $9.09 \pm 2.46$ \\
\hline \multicolumn{5}{|c|}{ Body diameter (cm) } \\
\hline Neck & $4.20 \pm 0.31$ & $4.66 \pm 0.20$ & $4.51 \pm 0.27$ & $4.23 \pm 0.14$ \\
\hline Vent & $7.12 \pm 0.71$ & $7.40 \pm 0.41$ & $7.55 \pm 0.68$ & $7.23 \pm 0.00$ \\
\hline Upper caudal & $4.24 \pm 0.32$ & $4.35 \pm 0.20$ & $4.37 \pm 0.26$ & $4.13 \pm 0.18$ \\
\hline \multicolumn{5}{|c|}{ Orifices diameter (mm) } \\
\hline Cloacae & $3.48 \pm 1.42$ & $3.18 \pm 0.85$ & $2.40 \pm 0.47$ & $2.42 \pm 0.20$ \\
\hline Vagina (right) & $2.07 \pm 0.80$ & $1.30 \pm 0.60$ & $1.89 \pm 1.04$ & $1.81 \pm 0.50$ \\
\hline Vagina (left) & $1.89 \pm 0.64$ & $1.24 \pm 0.54$ & $1.71 \pm 1.09$ & $1.96 \pm 0.14$ \\
\hline
\end{tabular}

TABLE 3: Mean values of ovaries dimensions of Bostanabad Zanjani viper in four seasons $(M \pm S D)$.

\begin{tabular}{|c|c|c|c|c|}
\hline \multirow{2}{*}{ Ovary parameters } & \multicolumn{4}{|c|}{ Season } \\
\hline & Spring & Summer & Autumn & Winter \\
\hline \multicolumn{5}{|l|}{ Right ovary } \\
\hline Length (mm) & $71.29 \pm 10.70$ & $54.12 \pm 13.25$ & $58.44 \pm 3.80$ & $46.91 \pm 6.10$ \\
\hline Width (mm) & $9.19 \pm 2.59$ & $6.23 \pm 3.32$ & $6.81 \pm 0.62$ & $6.78 \pm 1.91$ \\
\hline Diameter $(\mathrm{mm})$ & $3.77 \pm 1.06$ & $2.68 \pm 1.42$ & $3.25 \pm 0.19$ & $2.98 \pm 1.06$ \\
\hline Volume $\left(\mathrm{mm}^{3}\right)$ & $3493.2 \pm 1515.11$ & $1819.13 \pm 206.39$ & $1440.83 \pm 203.66$ & $1069.43 \pm 485.78$ \\
\hline Weight (g) & $1.79 \pm 0.74$ & $1.03 \pm 0.46$ & $0.98 \pm 0.26$ & $0.76 \pm 0.28$ \\
\hline \multicolumn{5}{|l|}{ Left ovary } \\
\hline Length (mm) & $49.86 \pm 11.63$ & $35.70 \pm 10.33$ & $37.83 \pm 0.43$ & $32.01 \pm 8.92$ \\
\hline Width (mm) & $8.99 \pm 2.24$ & $5.60 \pm 2.37$ & $6.99 \pm 0.04$ & $7.59 \pm 1.99$ \\
\hline Diameter $(\mathrm{mm})$ & $3.92 \pm 1.02$ & $2.72 \pm 1.14$ & $2.63 \pm 0.41$ & $3.49 \pm 1.17$ \\
\hline Volume $\left(\mathrm{mm}^{3}\right)$ & $3182.32 \pm 1408.54$ & $951.56 \pm 351.56$ & $1097.68 \pm 951.15$ & $1005.28 \pm 450.5$ \\
\hline Weight (g) & $1.30 \pm 0.55$ & $0.59 \pm 0.15$ & $0.73 \pm 0.24$ & $0.64 \pm 0.24$ \\
\hline
\end{tabular}

TABLE 4: Mean values of ovaries dimensions of Tarom Zanjani viper in four seasons $(M \pm S D)$.

\begin{tabular}{|c|c|c|c|c|}
\hline \multirow{2}{*}{ Ovary parameters } & \multicolumn{4}{|c|}{ Season } \\
\hline & Spring & Summer & Autumn & Winter \\
\hline \multicolumn{5}{|l|}{ Right ovary } \\
\hline Length (mm) & $54.61 \pm 13.01$ & $53.44 \pm 8.65$ & $45.39 \pm 8.64$ & $42.71 \pm 14.68$ \\
\hline Width (mm) & $6.80 \pm 2.22$ & $4.11 \pm 0.48$ & $5.66 \pm 1.88$ & $5.73 \pm 1.03$ \\
\hline Diameter $(\mathrm{mm})$ & $3.00 \pm 0.94$ & $1.48 \pm 0.24$ & $3.22 \pm 1.09$ & $2.81 \pm 0.61$ \\
\hline Volume $\left(\mathrm{mm}^{3}\right)$ & $1376.26 \pm 508.91$ & $478.54 \pm 139.96$ & $894.78 \pm 158.09$ & $771.53 \pm 107.4$ \\
\hline Weight (g) & $1.01 \pm 0.61$ & $0.41 \pm 0.08$ & $0.70 \pm 0.19$ & $0.6 \pm 0.20$ \\
\hline \multicolumn{5}{|l|}{ Left ovary } \\
\hline Length (mm) & $41.81 \pm 11$ & $31.80 \pm 4.49$ & $32.70 \pm 6.56$ & $33.56 \pm 0.23$ \\
\hline Width (mm) & $7.66 \pm 2.56$ & $5.19 \pm 1.14$ & $6.27 \pm 1.62$ & $5.04 \pm 1.46$ \\
\hline Diameter $(\mathrm{mm})$ & $3.45 \pm 1.71$ & $1.66 \pm 0.52$ & $2.82 \pm 0.53$ & $2.69 \pm 0.03$ \\
\hline Volume $\left(\mathrm{mm}^{3}\right)$ & $1588.5 \pm 446.76$ & $471.90 \pm 208.90$ & $709.15 \pm 115.19$ & $471.61 \pm 49.98$ \\
\hline Weight (g) & $0.95 \pm 0.73$ & $0.34 \pm 0.10$ & $0.54 \pm 0.15$ & $0.40 \pm 0.16$ \\
\hline
\end{tabular}




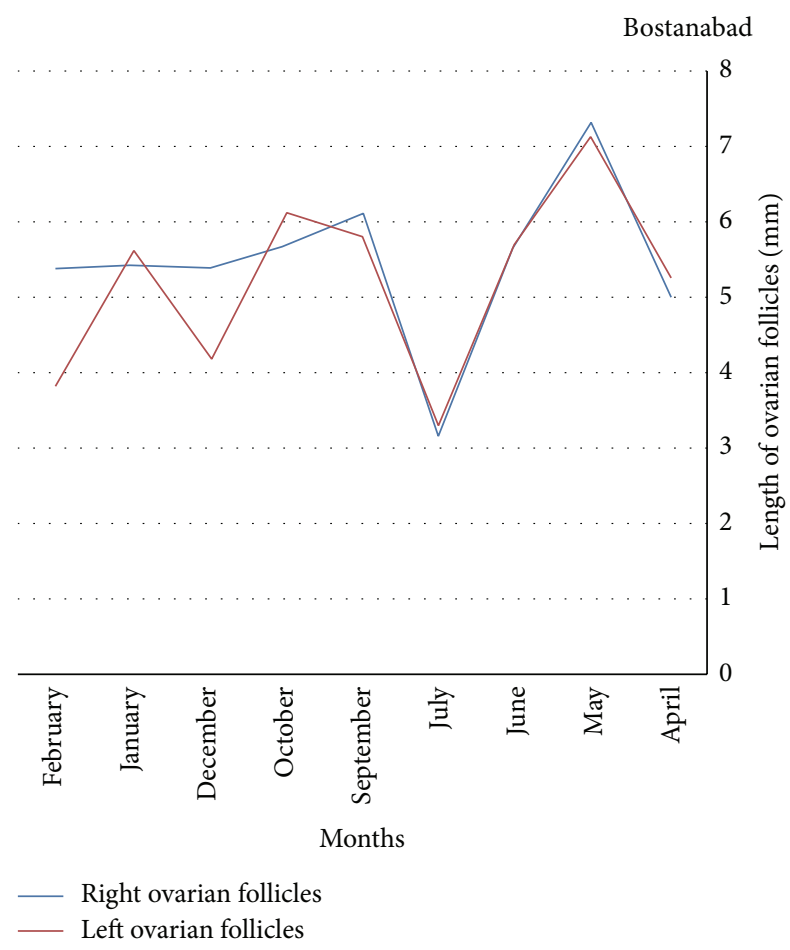

FIGURE 3: Size of ovarian follicles in Bostanabad V. albicornuta.

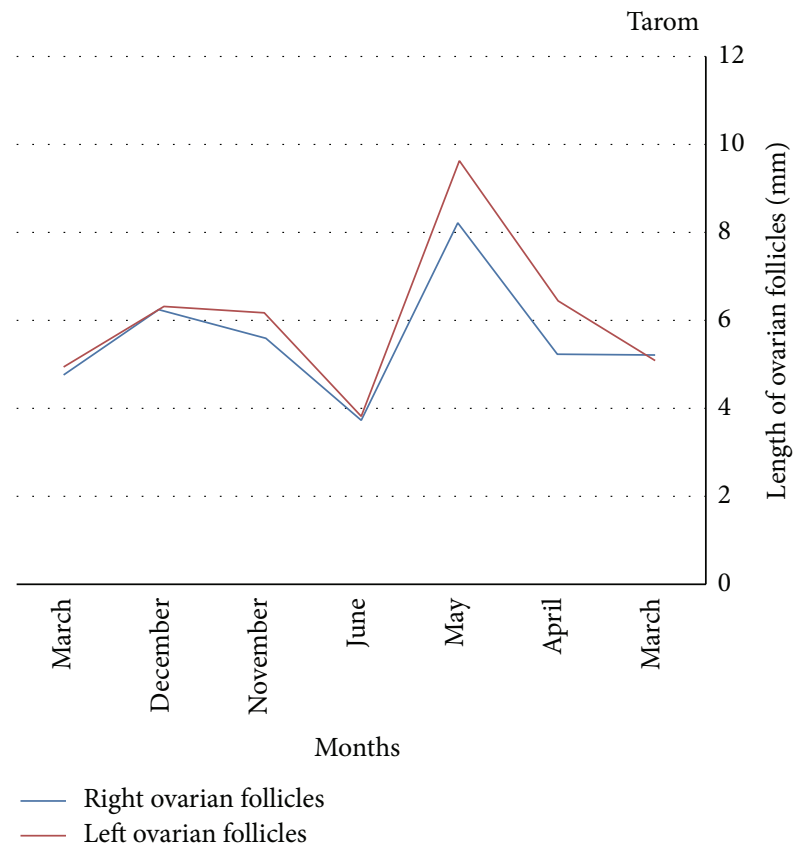

Figure 4: Size of ovarian follicles in Tarom V. albicornuta.

early May to June (Figure 5(a)) and postovulatory follicles in July (Figure 5(b)) which revealed that ovulation occurred in spring (early May till June). Previtellogenic follicles had many type pyriform cells in the granulose layer: small, medium, and large but vitellogenic follicles were only small pyriform cell (Figure 6(a)). Weights of right ovaries were more than left at $p<0.001$ and dramatically increased in spring. In
TABLE 5: Mean size and number of the ovaries follicles of Bostanabad Zanjani viper in four seasons $(\mathrm{M} \pm \mathrm{SD})$.

\begin{tabular}{lcccc}
\hline \multirow{2}{*}{ Follicles } & \multicolumn{4}{c}{ Season } \\
& Spring & Summer & Autumn & Winter \\
\hline Right ovary & & & & \\
$\quad$ Number & $23.86 \pm 7.08$ & $21.82 \pm 3.66$ & $21.58 \pm 1.53$ & $21.96 \pm 9.60$ \\
$\quad$ Size $(\mathrm{mm})$ & $6.20 \pm 1.60$ & $4.43 \pm 1.85$ & $5.81 \pm 0.30$ & $5.40 \pm 0.03$ \\
Left ovary & & & & \\
$\quad$ Number & $18.14 \pm 4.85$ & $16.82 \pm 3.97$ & $13.66 \pm 2.35$ & $16.06 \pm 5.10$ \\
Size $(\mathrm{mm})$ & $6.18 \pm 1.35$ & $4.50 \pm 1.72$ & $6.05 \pm 0.20$ & $4.95 \pm 0.99$ \\
\hline
\end{tabular}

TABLE 6: Mean size and number of the ovaries follicles of Tarom Zanjani viper in four seasons $(\mathrm{M} \pm \mathrm{SD})$.

\begin{tabular}{lcccc}
\hline \multirow{2}{*}{ Follicles } & \multicolumn{4}{c}{ Season } \\
& \multicolumn{1}{c}{ Spring } & Summer & Autumn & Winter \\
\hline Right ovary & & & & \\
$\quad$ Number & $19.25 \pm 3.77$ & $21.33 \pm 5.75$ & $16.11 \pm 10.15$ & $19.16 \pm 6.83$ \\
$\quad$ Size $(\mathrm{mm})$ & $6.26 \pm 1.75$ & $3.75 \pm 1.43$ & $5.59 \pm 2.97$ & $5.62 \pm 0.86$ \\
Left ovary & & & & \\
$\quad$ Number & $15.13 \pm 1.96$ & $17.50 \pm 1.87$ & $9.67 \pm 3.24$ & $14.25 \pm 6.01$ \\
Size (mm) & $7.05 \pm 2.34$ & $3.86 \pm 1.65$ & $6.21 \pm 2.96$ & $5.55 \pm 1.11$ \\
\hline
\end{tabular}

TABLE 7: Mean percentages of different types of follicles in the ovaries of Bostanabad Zanjani viper in four seasons $(M \pm S D)$.

\begin{tabular}{lcccc}
\hline \multirow{2}{*}{ Follicles type (\%) } & \multicolumn{5}{c}{ Season } \\
& Spring & Summer & Autumn & Winter \\
\hline Right ovary & & & & \\
Type I & $51.09 \%$ & $80.93 \%$ & $51.47 \%$ & $59.78 \%$ \\
Type II & $43.95 \%$ & $15.81 \%$ & $48.53 \%$ & $40.22 \%$ \\
Type III & $4.96 \%$ & $3.25 \%$ & 0 & 0 \\
Type IV & 0 & 0 & 0 & 0 \\
Left ovary & & & & \\
Type I & $51.74 \%$ & $82.23 \%$ & $44.73 \%$ & $64.56 \%$ \\
Type II & $42.65 \%$ & $16.44 \%$ & $55.27 \%$ & $35.44 \%$ \\
Type III & $6.29 \%$ & $1.31 \%$ & 0 & 0 \\
Type IV & 0 & 0 & 0 & 0 \\
\hline
\end{tabular}

Bostanabad samples length of ovarian follicle was large in summer (June and May) (Table 5), and the follicular length for Tarom's was at peak in early summer (June) and it was decreased in midsummer (July) (Table 6). The percentages of different types of ovarian follicles of the viper are presented in Tables 7 and 8.

\section{Discussion}

Snout-vent length (SVL) is commonly reported for body size in snakes [21]. SVL is correlated with litters or clutch's size in many species $[13,16]$. Maximum mean SVL of Bostanabad Vipera albicornuta was $68.43 \pm 2.98 \mathrm{~cm}$ and for Tarom samples $63.96 \pm 3.77 \mathrm{~cm}$. The previous studies have reported the SVL of $55.86 \pm 1.32 \mathrm{~cm}$ for female V. albicornuta [22] and $73.56 \pm 3.77 \mathrm{~cm}$ for male V. albicornuta [23], for pit viper, 


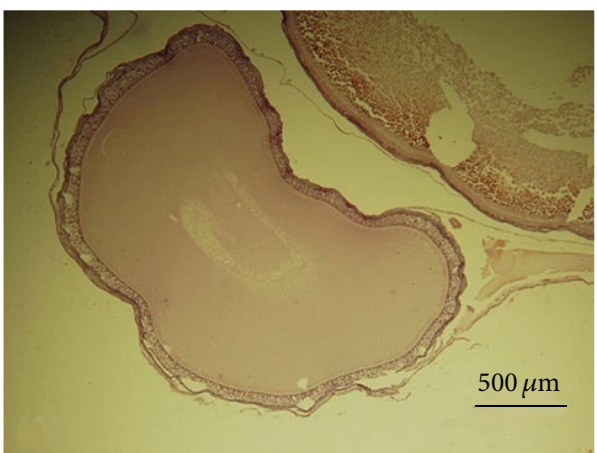

(a)

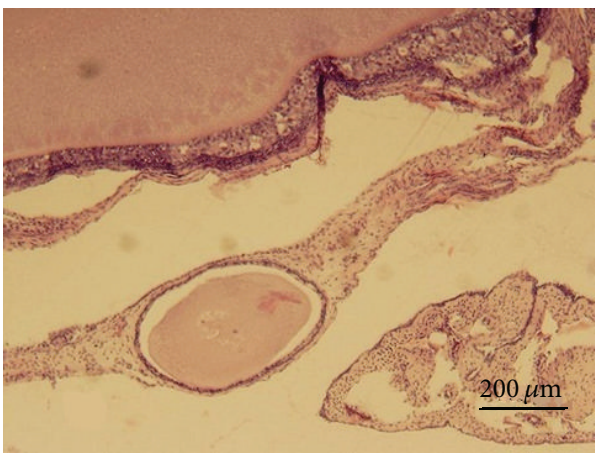

(c)

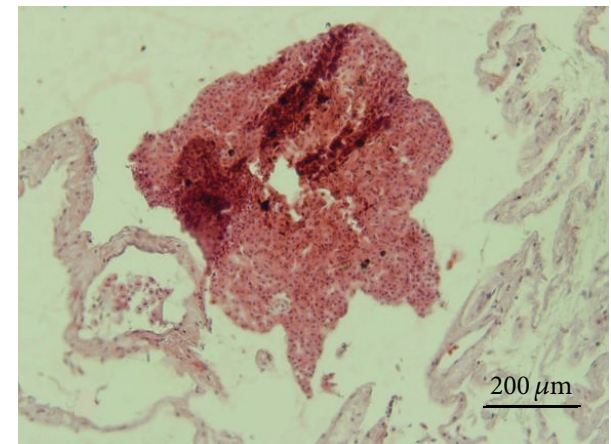

(b)

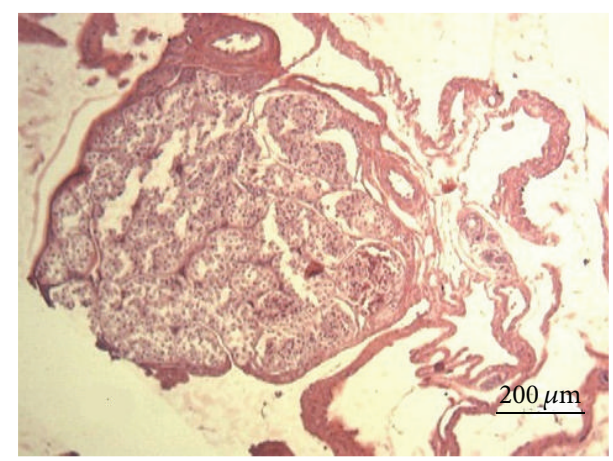

(d)

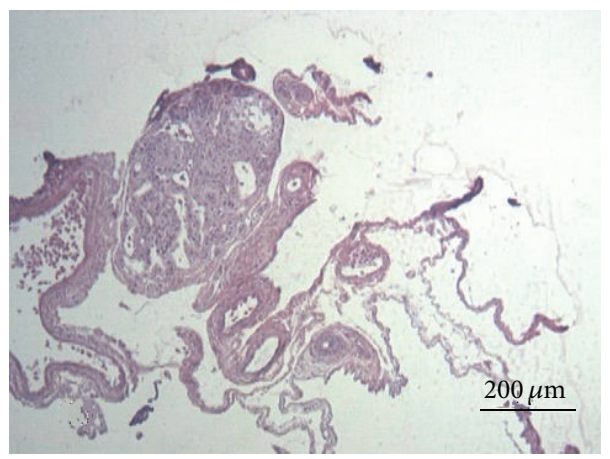

(e)

Figure 5: Micrographs of the Vipera albicornuta ovary. (a) Developing follicle in spring (July); (b) postovulatory follicle in summer; (c) previtellogenic follicle in fall; (d) the corpora lutea that regressed (Feb.); (e) corpora atretica in winter (Mar.). Scale bars: (a) $500 \mu \mathrm{m}$; (b), (c), (d), and (e) $200 \mu \mathrm{m}$.

Gloydius halys caucasicus, from Northwestern Iran $45.07 \pm$ $2.83 \mathrm{~cm}[24]$, and body length in Crotalus durissus terrificus was reported as $89.00 \pm 1.26 \mathrm{~cm}$ [25]. In Bostanabad Vipera albicornuta mean of tail length was $5.43 \pm 0.67 \mathrm{~cm}$ and for Tarom samples $5.24 \pm 0.50 \mathrm{~cm}$ similar to other studies, $5 \mathrm{~cm}$ [1], $4.61 \pm 0.9 \mathrm{~cm}$ in female [22] and $5.0 \pm 0.49 \mathrm{~cm}$ for male [24] Zanjani vipers and $6.07 \pm 0.85 \mathrm{~cm}$ for Gloydius halys caucasicus, but compared to the female Elaphe rufodorsata, $10.7 \mathrm{~cm}$ and in male $11.2 \mathrm{~cm}$ were smaller [26]. Body size is the important biological trait for snakes, reproductive behavior such as fecundity in female or greater rates of mating in male [27]. Maximum average body weight of the Bostanabad $V$. albicornuta was $213.33 \pm 30 \mathrm{~g}$ in spring (May), fat weight 24.93 $\pm 5.62 \mathrm{~g}$ in fall (November), and in the Tarom viper it was $142.82 \pm 31.41 \mathrm{~g}$ in spring and fat weight $17.36 \pm 3.55 \mathrm{~g}$ in the fall; therefore the V. albicornuta compared to the Gloydius halys caucasicus, $51.5 \pm 10.42 \mathrm{~g}$ [24], is larger snake, although the results revealed that $V$. albicornuta is medium size snake [28] and Bostanabad V. albicornuta is larger than Tarom's one. Body fat reserves have shown the phase of hibernation and reveal a significant increase [29]. Body weight of female snakes shows an increase in fall could be due to fat storage for hibernation and in spring as a result of their feeding after emergence to prepare for motherhood. Snakes with weak bodies cannot produce the good clutch during reproductive seasons like Elaphe longissima [30], Vipera aspis [31]. Body fat of viviparous cortalid is reduced during the vitellogenesis, the hibernation, and also pregnancy period and lack of nutrition $[11,15,32,33]$. Weight of body fat is reduced during the pregnancy and vitellogenesis in the $V$. albicornuta that is 


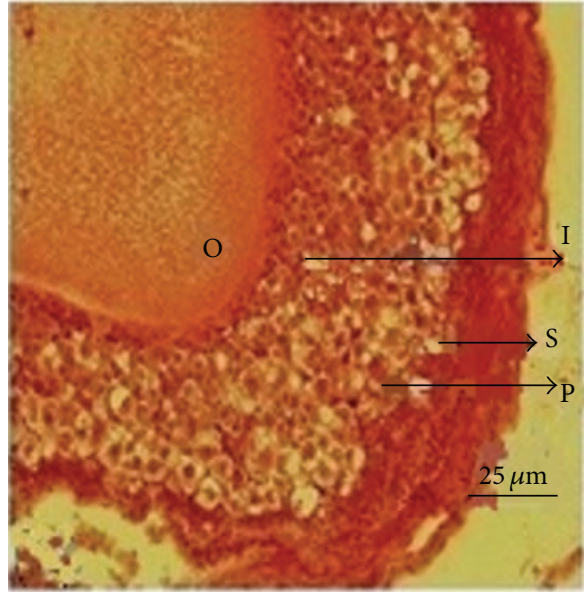

(a)

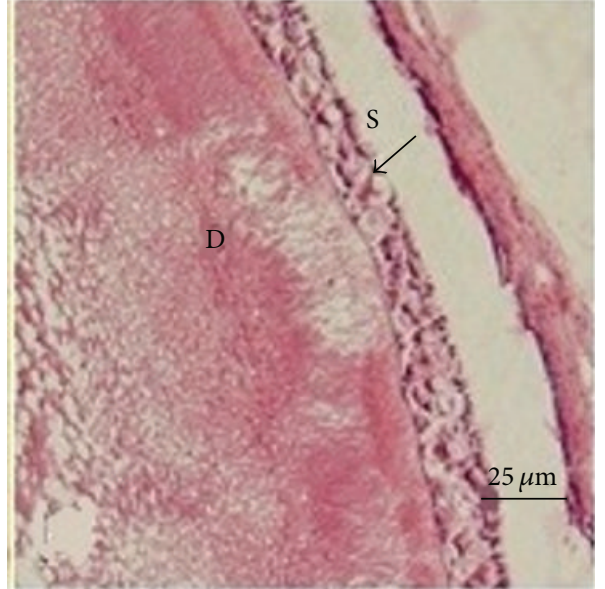

(b)

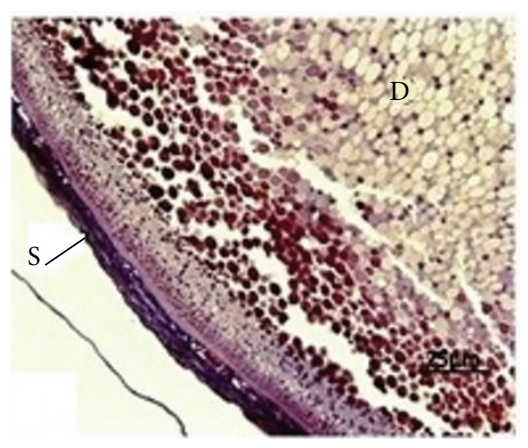

(c)

FiguRE 6: Sections of Vipera albicornuta ovary $(\mathrm{H} \times \mathrm{E})$. (a) Stage I follicle (primary follicle): the former is $<5 \mathrm{~mm}$ in length. No deutoplasmic granules were found in the ooplasm. The granulose contained pyriform, intermediate and small cells. (b) Stage II follicle: 5-15 mm in length. Deutoplasmic granules started to form and 2-3 layers of small cells existed in the granulose. (c) Stage III follicle: 15-25 mm in the length. The number and size of deutoplasmic granules increased, but there was only one layer of follicular cells. D: deutoplasmic granules; I: intermediate cell; O: ooplasm; P: pyriform cell; S: small cell. Scale bars $=25 \mu \mathrm{m}$.

TABle 8: Mean percentages of different types of follicles in the ovaries of Tarom Zanjani viper in four seasons $(\mathrm{M} \pm \mathrm{SD})$.

\begin{tabular}{lcccc}
\hline \multirow{2}{*}{ Follicles type (\%) } & \multicolumn{4}{c}{ Season } \\
& Spring & Summer & Autumn & Winter \\
\hline Right ovary & & & & \\
Type I & $62.79 \%$ & $88.77 \%$ & $50.34 \%$ & $50.34 \%$ \\
Type II & $33.72 \%$ & $11.23 \%$ & $49.66 \%$ & $49.66 \%$ \\
Type III & $20.09 \%$ & 0 & 0 & 0 \\
Type IV & 0 & 0 & 0 & 0 \\
Left ovary & & & & \\
Type I & $52.23 \%$ & $93.90 \%$ & $40.22 \%$ & $40.22 \%$ \\
Type II & $40.29 \%$ & $6.10 \%$ & $59.77 \%$ & $59.77 \%$ \\
Type III & $11.94 \%$ & 0 & 0 & 0 \\
Type IV & 0 & 0 & 0 & 0 \\
\hline
\end{tabular}

similar to Trimeresurus stejnegeri stejnegeri [4]. In spring ovarian volume of Bostanabad's samples was at peak in July and decreased in August. The maximum ovarian weight and volume were observed in Tarom's snakes in late May to early
June. As previously reported by Goldberg and Beaman [34] in Crotalus enyo and Crotalus oreganus snakes ovulation occurs in June [35]. Our study revealed that ovarian follicular growth in Bostanabad's Zanjani viper starts in fall and is at peak in spring, and mate is in late autumn, and the development of ovarian follicles continues till winter, because mating appears to have an obligatory role in the onset of vitellogenesis [36]. In aspic viper early vitellogenesis is reported during MarchApril [5]. Ovarian follicles continue to evolve in late spring when ovulation occurs. Development of ovarian follicles in Tarom's Vipera albicornuta is similar to Agkistrodon piscivorus of temperate regions [37, 38]. In female viper Bothrops insularis the vitellogenesis occurs in spring and ovulation occurs in late spring [9] as Tantilla coronata from the temperate region of South America [33]. Our result revealed that in Bostanabad's $V$. albicornuta ovulation probably occurred between June and July and in Tarom's vipers between May and June. The ovulation and mating in vipers usually occur at time that infants grow in the appropriate conditions. In some species, ovulation occurs in early summer so babies born in late summer [37, 38]. Our results show that there is difference at ovulation time between Tarom's and Bostanabad's vipers. 
This difference could be due to differences in the geographical conditions. Typically, ovarian cycles and follicular growth are correlated with periods of light, rain, moisture, and food sources $[39,40]$. Overall follicular growth in $V$. albicornuta is similar to nontoxic Storeria dekayi snake of Southeast Canada [10]. However, in the Zanjani viper, ovaries and follicles are at previtellogenesis stage in autumn, vitellogenesis in winter and during spring, ovulation occurs in late spring till early summer, and mating is prior to ovulation.

\section{Conflict of Interests}

The authors declare that there is no conflict of interests regarding the publication of this paper.

\section{Acknowledgment}

The authors gratefully acknowledge the staff of Venomous Animals and Pathology Laboratories in Razi Vaccine and Serum Research Institute, Karaj, Iran, for providing research facilities.

\section{References}

[1] M. Latifi, Snakes of Iran, Department of the Environment, 3rd edition, 1991.

[2] B. D. Palmer and L. J. Guillette Jr., "Histology and functional morphology of the female reproductive tract of the tortoise Gopherus polyphemus," American Journal of Anatomy, vol. 183, no. 3, pp. 200-211, 1988.

[3] S. P. Graham, R. L. Earley, S. K. Hoss, G. W. Schuett, and M. S. Grober, "The reproductive biology of male Cottonmouths (Agkistrodon piscivorus): do plasma steroid hormones predict the mating season?" General and Comparative Endocrinology, vol. 159, no. 2-3, pp. 226-235, 2008.

[4] T.-S. Tsai and M.-C. Tu, "Reproductive cycle of female Chinese green tree vipers, Trimeresurus stejnegeri stejnegeri, in northern Taiwan," Herpetologica, vol. 57, no. 2, pp. 157-168, 2001.

[5] X. Bonnet, O. Lourdais, R. Shine, and G. Naulleau, "Reproduction in a typical capital breeder: costs, currencies, and complications in the aspic viper," Ecology, vol. 83, no. 8, pp. 21242135, 2002.

[6] P. Tumkiratiwong, W. Meesuk, L. Chanhome, and A. Aowphol, "Reproductive patterns of captive male and female monocled cobra, Naja kaouthia (lesson, 1831)," Zoological Studies, vol. 51, no. 5, pp. 692-700, 2012.

[7] D. O. Norris, Vertebrate Endocrinology, Elsevier Academic Press, 2007.

[8] K. Parivar, Embryology, Originators Publications, 6th edition, 2004.

[9] S. M. Almeida-Santos, K. N. Kasperoviczus, and O. A. V. Marques, "Reproductive biology in an insular Golden Lancehead, Bothrops insularis," in Proceedings of the 2nd Biology of the Vipers Conference, pp. 24-27, Porto, Portugal, September 2007.

[10] C. P. Kofron, "Reproduction of aquatic snakes in south-central Louisiana," Herpetologica, vol. 35, pp. 44-50, 1979.

[11] R. Shine, "Reproduction in Australian elapid snakes II. Female reproductive cycles," Australian Journal of Zoology, vol. 25, no. 4, pp. 655-666, 1977.
[12] J. W. Gibbons, "Reproduction, growth, and sexual dimorphism in the canebrake rattlesnake (Crotalus horridus atricaudatus)," Copeia, vol. 1972, no. 2, pp. 222-226, 1972.

[13] L. J. Vitt and J. D. Congdon, "Body shape, reproductive effort, and relative clutch mass in lizards: resolution of a paradox," The American Naturalist, vol. 112, no. 985, pp. 595-608, 1978.

[14] C. P. Qualls, R. Shine, S. Donnellan, and M. Hutchinson, "The evolution of viviparity within the Australian scincid lizard Lerista bougainvillii," Journal of Zoology, vol. 237, no. 1, pp. 13-26, 1995.

[15] H. S. Fitch, Reproductive Cycles in Lizards and Snakes, vol. 52, Miscellaneous Publication-University of Kansas, Museum of Natural History, 1970.

[16] L. Kratochvíl and L. Kubička, "Why reduce clutch size to one or two eggs? Reproductive allometries reveal different evolutionary causes of invariant clutch size in lizards," Functional Ecology, vol. 21, no. 1, pp. 171-177, 2007.

[17] R. A. Seigel and H. S. Fitch, "Annual variation in reproduction in snakes in a fluctuating environment," Journal of Animal Ecology, vol. 54, no. 2, pp. 497-505, 1985.

[18] M. H. Cha, B. C. Ahn, and Y. S. Kim, "Inaccuracy in ultrasonographic measurement of the testicular volume in children," Korean Journal of Urology, vol. 47, no. 8, pp. 866-869, 2006.

[19] T. W. Betz, "The gross ovarian morphology of the diamondbacked water snake, Natrix rhombifera, during the reproductive cycle," Copeia, vol. 1963, no. 4, pp. 692-697, 1963.

[20] L. G. Luna, Manual of Histologic Staining Methods of the Armed Forces Institute of Pathology, McGraw Hill, New York, NY, USA, 3rd edition, 1968.

[21] H. S. Fitch, "Collecting and life history techniques," in Snakes: Ecology and Evolutionary Biology, R. A. Siegel, J. T. Collins, and S. S. Novak, Eds., pp. 143-163, McGraw-Hill, New York, NY, USA, 1987.

[22] M. Takfallah, Study of reproductive duct in female Vipera albicornuta before and after hibernation [M.S. thesis], University of Tehran, Tehran, Iran, 2011.

[23] M. Moshiri, A. Shiravi, and F. Todehdehghan, "Study of sperm reproductive parameters in mature Zanjani viper," Cell Journal, vol. 16, no. 2, pp. 111-116, 2014.

[24] Z. Mozafari, A. Shiravi, and F. Todehdehghan, "Evaluation of reproductive parameters of vas deferens sperms in Caucasian snake (Gloydius halys caucasicus)," Veterinary Research Forum, vol. 3, no. 2, pp. 119-123, 2012.

[25] S. M. Almeida-Santos and M. G. Salomao, "Long-term sperm storage in the Neotropical rattlesnake Crotalus durissus terrificus (Viperidae: Crotalinae)," Japanese Journal of Herpetology, vol. 17, pp. 46-52, 1997.

[26] X. Ji, Y.-Y. Xie, P.-Y. Sun, and X.-Z. Zheng, "Sexual dimorphism and female reproduction in a viviparous snake, Elaphe rufodorsata," Journal of Herpetology, vol. 31, no. 3, pp. 420-422, 1997.

[27] C. Magnhagen, "Predation risk as a cost of reproduction," Trends in Ecology and Evolution, vol. 6, no. 6, pp. 183-186, 1991.

[28] G. R. Zug, L. J. Vitt, and J. P. Caldwell, Herpetology: An Introductory Biology of Amphibians and Reptiles, Academic Press, 7th edition, 2008.

[29] S. El-Deib, "Lipid changes in blood serum and tissues of the Egyptian Cobra 'Naja haje haje' during the hibernation cycle," Journal of Thermal Biology, vol. 30, no. 1, pp. 51-59, 2005.

[30] M. Capula, E. Filippi, and L. Luiselli, "Annual mating in female colubrid snakes with irregular reproductive frequency," Herpetol, vol. 8, no. 1-2, pp. 11-15, 1995. 
[31] H. Saint-Girons, "Le cycle sexuel chez (Vipera aspis) dans pouest de la France," Bulletin Biologique de France et de Belgique, vol. 91, pp. 284-350, 1957.

[32] J. M. Macartney and P. T. Gregory, "Reproductive biology of female rattlesnakes (Crotalus viridis) in British Columbia," Copeia, vol. 1988, no. 1, pp. 47-57, 1988.

[33] R. D. Aldridge, "Oviductal anatomy and seasonal sperm storage in the Southeastern Crowned snake (Tantilla coronata)," Copeia, vol. 1992, no. 4, pp. 1103-1106, 1992.

[34] S. R. Goldberg and K. R. Beaman, "Reproduction in the Baja California rattlesnake, Crotalus enyo (Serpents: Viperidae) Bull South Calif," Bulletin of the Southern California Academy of Sciences, vol. 102, pp. 39-42, 2003.

[35] L. V. Diller and R. L. Wallace, "Reproductive biology of the Northern Pacific rattlesnake (Crotalus viridis oreganus) in Northern Idaho," Herpetologica, vol. 40, no. 2, pp. 182-193, 1984.

[36] M. T. Mendonça and D. Crews, "Mating-induced ovarian recrudescence in the red-sided garter snake," Journal of Comparative Physiology A, vol. 166, no. 5, pp. 629-632, 1990.

[37] R. D. Aldridge and D. Duvall, "Evolution of the mating season in the pitvipers of North America," Herpetological Monographs, no. 16, pp. 1-25, 2002.

[38] D. S. Siegel and D. M. Sever, "Seasonal variation in the oviduct of female Agkistrodon piscivorus (Reptilia: Squamata): an ultrastructural investigation," Journal of Morphology, vol. 269, no. 8, pp. 980-997, 2008.

[39] J. M. Whittier and D. Crews, "Ovarian development in redsided garter snakes, Thamnophis sirtalis parietalis: relationship to mating," General and Comparative Endocrinology, vol. 61, no. 1, pp. 5-12, 1986.

[40] A. F. Flemming, "The male reproductive cycle of the lizard Pseudocordylus m. melanotus (Sauria: Cordylidae)," Journal of Herpetology, vol. 27, no. 4, pp. 473-478, 1993. 

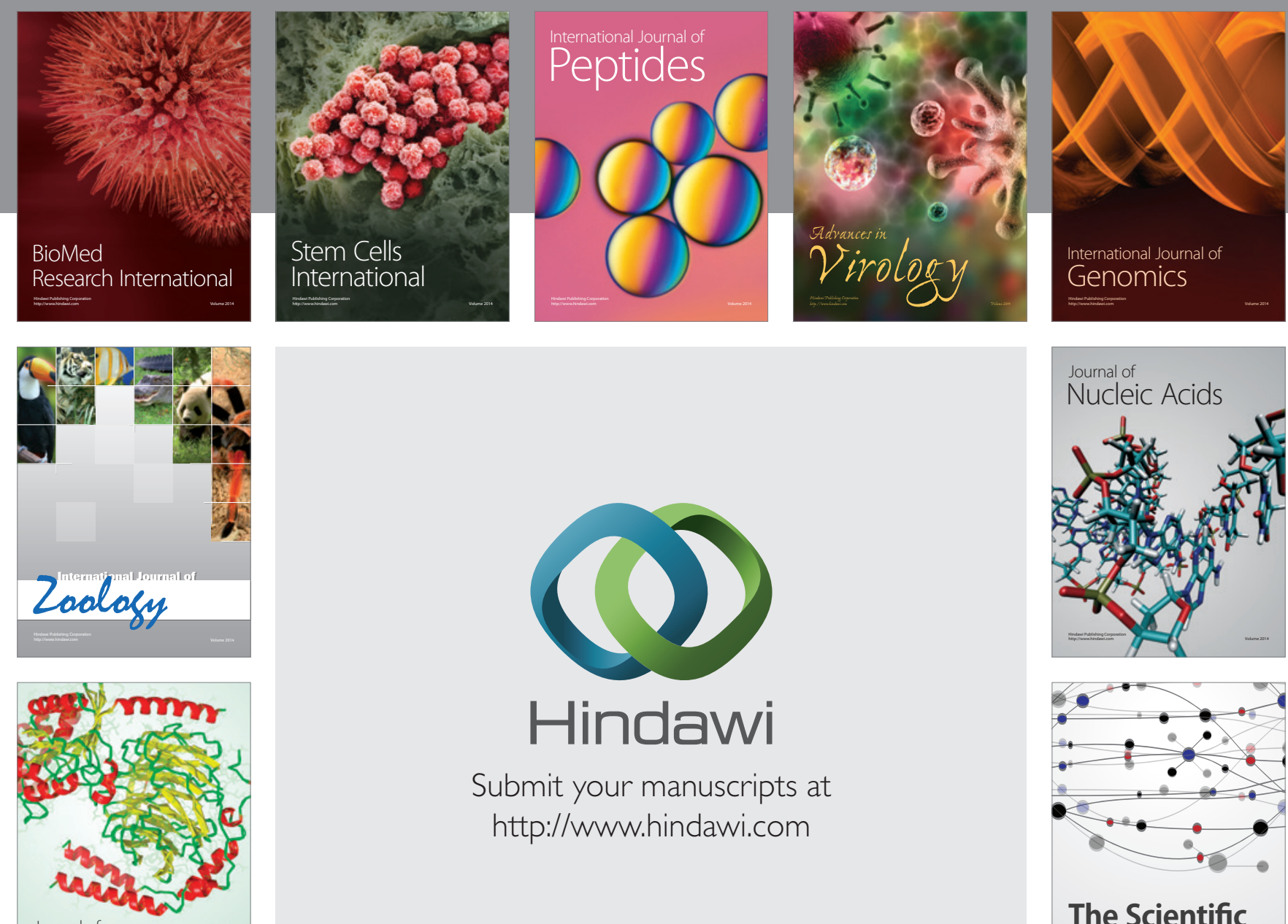

Submit your manuscripts at

http://www.hindawi.com

Journal of
Signal Transduction
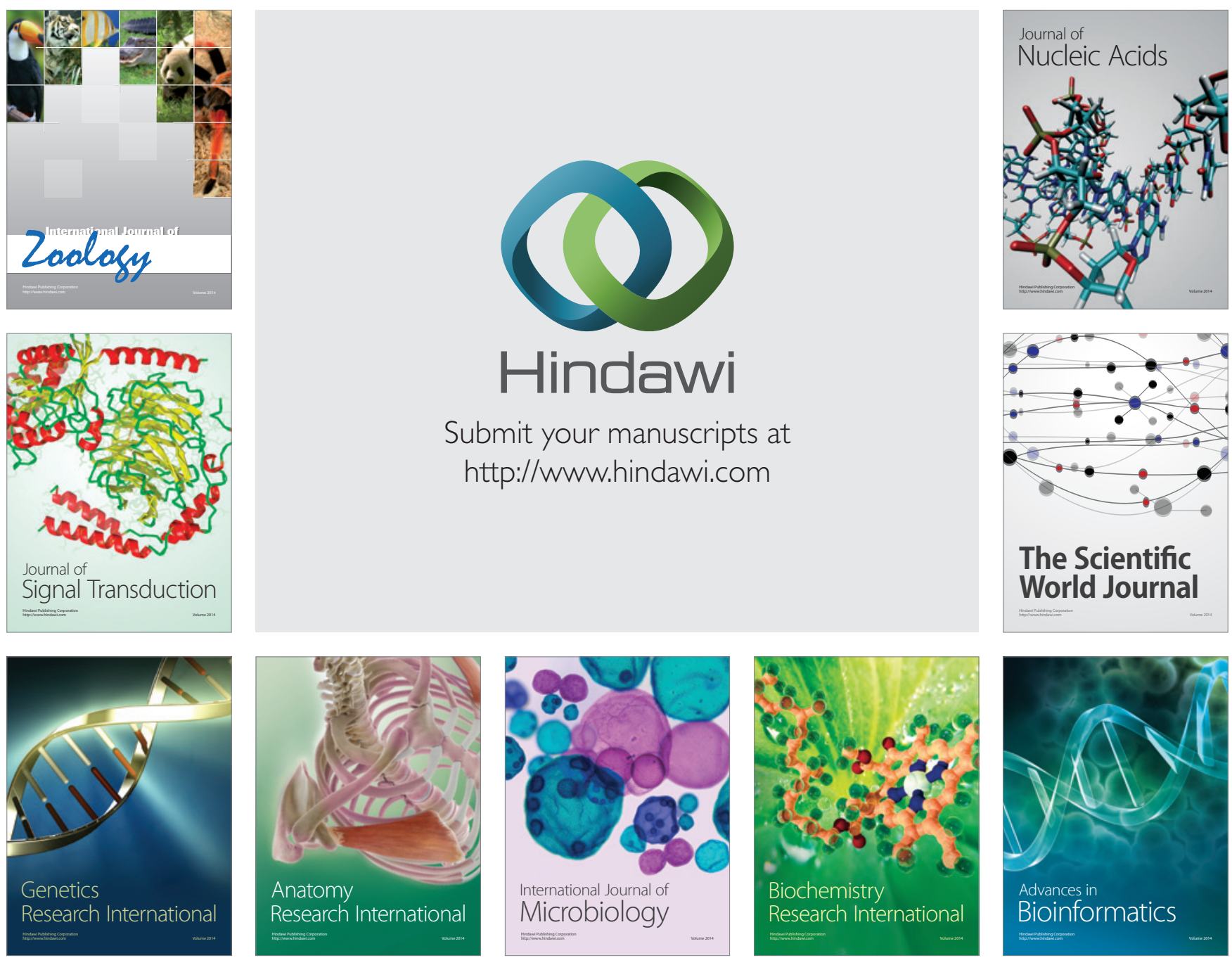

The Scientific World Journal
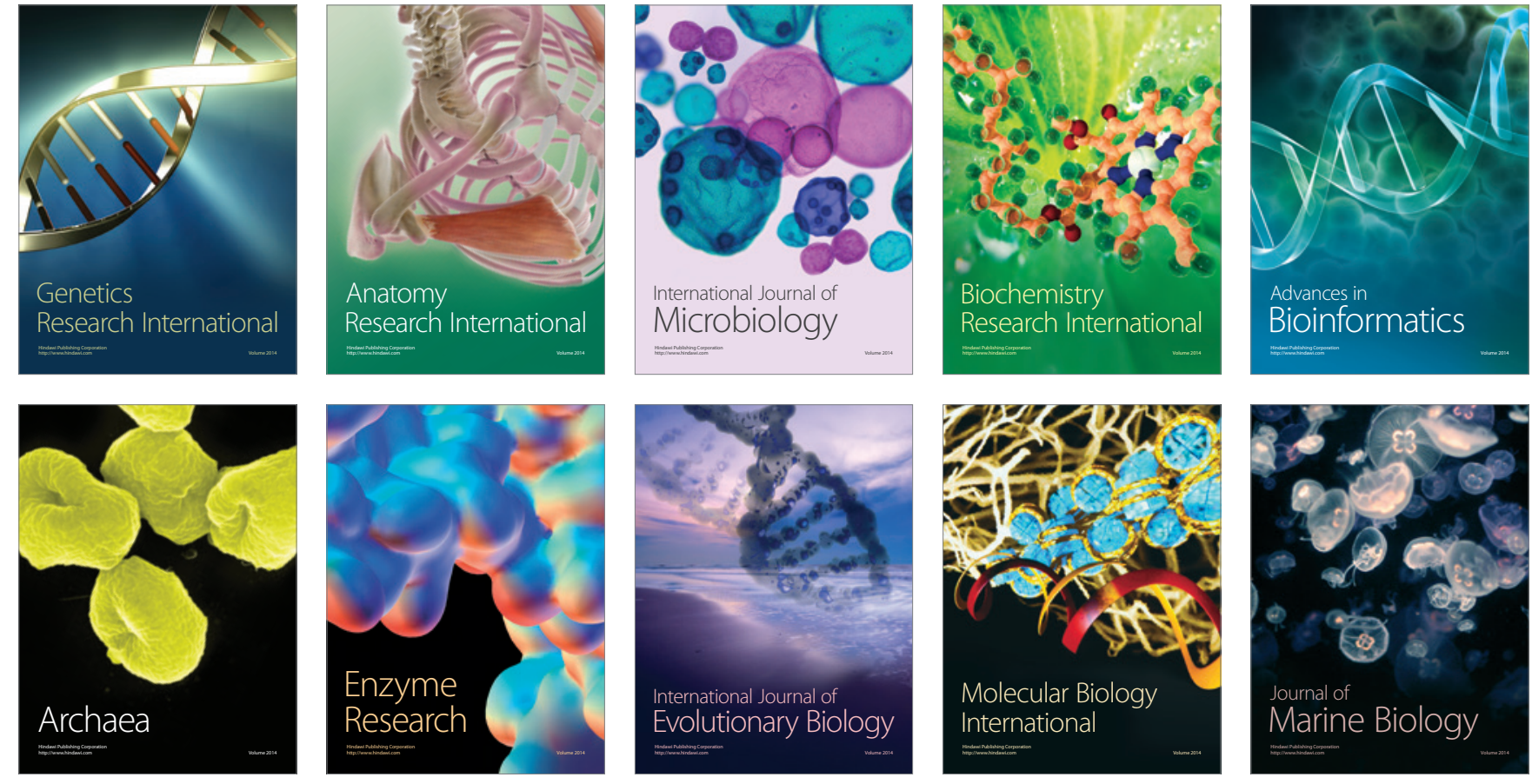